Article

\title{
Genetic Variants in pre-miR-146a, pre-miR-499, pre-miR-125a, pre-miR-605, and pri-miR-182 Are Associated with Breast Cancer Susceptibility in a South American Population
}

\author{
Sebastián Morales ${ }^{1}$, Tomas De Mayo ${ }^{2}$, Felipe Andrés Gulppi ${ }^{1}$, Patricio Gonzalez-Hormazabal ${ }^{1}$ (iD), \\ Valentina Carrasco ${ }^{1}$, José Miguel Reyes ${ }^{3}$, Fernando Gómez ${ }^{4}$, Enrique Waugh ${ }^{4}$ and Lilian Jara ${ }^{1, *}$ (iD \\ 1 Human Genetics Program, Institute of Biomedical Sciences (ICBM), School of Medicine, University of Chile, \\ Santiago 8380453, Chile; seba.morales.p@gmail.com (S.M.); felipe.gulppi@gmail.com (F.A.G.); \\ pgonzalez@med.uchile.cl (P.G.-H.); valentina.carrasco@gmail.com (V.C.) \\ 2 Center for Genetics and Genomics, School of Medicine, Clínica Alemana Universidad del Desarrollo, \\ Santiago 7610658, Chile; tdemayog@udd.cl \\ 3 Clínica Las Condes, Santiago 7591047, Chile; jmreyes@clc.cl \\ 4 Clínica Santa María, Santiago 7520378, Chile; fgomez@csm.cl (F.G.); ewaugh@csm.cl (E.W.) \\ * Correspondence: ljara@gmail.com; Tel.: +562-29786166
}

Received: 26 June 2018; Accepted: 17 August 2018; Published: 22 August 2018

\begin{abstract}
Breast cancer (BC) is one of the most frequent tumors affecting women worldwide. microRNAs (miRNAs) single-nucleotide polymorphisms (SNPs) likely contribute to BC susceptibility. We evaluated the association of five SNPs with BC risk in non-carriers of the BRCA1/2-mutation from a South American population. The SNPs were genotyped in 440 Chilean $B R C A 1 / 2$-negative BC cases and 1048 controls. Our data do not support an association between rs2910164:G>C or rs3746444:A>G and BC risk. The rs12975333:G $>\mathrm{T}$ is monomorphic in the Chilean population. The pre-miR-605 rs2043556-C allele was associated with a decreased risk of $B C$, both in patients with a strong family history of $B C$ and in early-onset non-familial BC (Odds ratio (OR) $=0.5$ [95\% confidence interval (CI) 0.4-0.9] $p=0.006$ and $\mathrm{OR}=0.6[95 \% \mathrm{CI} 0.5-0.9] p=0.02$, respectively). The rs4541843-T allele is associated with increased risk of familial BC. This is the first association study on rs4541843 and BC risk. Previously, we showed that the TOX3-rs3803662:C>T was significantly associated with increased risk of familial BC. Given that TOX3 mRNA is a target of miR-182, and that both the TOX3 rs3803662-T and pri-miR-182 rs4541843-T alleles are associated with increased BC risk, we evaluated their combined effect. Risk of familial BC increased in a dose-dependent manner with the number of risk alleles $(p$-trend $=0.0005)$, indicating an additive effect.
\end{abstract}

Keywords: familial breast cancer; polymorphisms; microRNA; South American population

\section{Introduction}

Breast cancer $(\mathrm{BC})$ is one of the most frequent cancers affecting women worldwide. One of every eight women will develop BC in their lifetime [1]. In Chile, BC has the highest mortality rate among cancers (15.69/100,000 women), and its incidence is rising in all of the age groups monitored [2]. The mutations in the $B R C A 1 / 2$ genes are responsible for an average of $16-20 \%$ of the risk for hereditary $B C$ [3-5]. Moreover, it has been proposed that BC susceptibility alleles can be classified into three categories of penetrance (high, moderate, or low) that reflect the probability of developing the disease [6]. Our group has studied the contribution of moderate- and low-penetrance genes (PALB2 [7], BARD1 [8], ATM [9], CHECK2 [10], FGFR2 [11], TOX3 [12], MAP3K1 [11], and 8q24 [12]) to genetic susceptibility to hereditary 
$\mathrm{BC}$ in the Chilean population. As genetic factors play an important role in $\mathrm{BC}$ etiology [13], identifying the genetic alterations involved in breast carcinogenesis is a major priority in the field.

In recent years, evidence has emerged to support a role for microRNAs (miRNAs) in BC development and progression [14,15]. miRNAs are single-stranded RNAs of about 22 nucleotides in length. These molecules can regulate gene expression by degrading or blocking the translation of their specific target mRNAs, mainly by binding to their $3^{\prime}$-untranslated region (UTR) $[16,17]$. Approximately $30 \%$ of all of the human genes are regulated by miRNAs [18,19]. Growing evidence has established that miRNA misexpression and mutations are correlated with various human cancers, including BC [20-22]. Single-nucleotide polymorphisms (SNPs) are the most common type of variation in the human genome. The SNPs present in miRNAs can alter the expression, lead to the maturation of aberrant miRNA, and affect the target binding affinity and specificity. Therefore, these variants may contribute to some forms of familial cancer [23]. Many epidemiological studies have examined the association between miRNA SNPs and cancer susceptibility [22]. In BC, several case-control studies and meta-analyses have evaluated the association between the miRNA gene polymorphisms and disease risk in European [24-29], Asian [30,31], Arab [32], Jewish [33], and Iranian populations [34]. With the exception of two studies, one in a Brazilian [35] and the other in Chilean population published by our group [36], the contribution of miRNA gene variants to BC risk among South American women remains unexplored. We have previously studied the contribution of the SNPs rs895819 (pre-miR-27a), rs11614913 (pre-miR-196a2), rs6505162 (pre-miR-423), rs4919510 (miR-608), and rs2682818 (pre-miR-618) to BC susceptibility in the Chilean population, as these were the most-studied SNPs in the BC cases from several populations. Moreover, the genetic variability is ethnicity-specific and appears to influence not only the risk but also the type of $\mathrm{BC}$ that develops in an individual. In this study, we selected SNPs in three miRNAs (rs3746444 in pre-miR-499, rs12975333 in pre-miR-125a, and rs2043556 in miR-605), based on the evidence in the literature for a relationship with BC risk [23,24,31,34,37-39]. Another four miRNAs (pre-miR-16, pre-miR-182, pre-miR-192, and pre-miR-146a) were also selected for analysis, as these miRNAs are known to target BRCA1/2 genes [40-43]. Therefore, in this study, we sequenced the complete coding regions and boundaries of pre-miR-16, pre-miR-182, pre-miR-192, and pre-miR-146a in a population of Chilean BC patients who were negative for $B R C A 1$ and $B R C A 2$ mutations, with the aim of identifying new variants. The patients had either a strong family history of BC or of early-onset BC. The SNPs were identified in only two of the miRNAs sequenced, pre-miR-146a (rs2910164) and pri-miR-182 (rs4541843). A case-control designed was used to assess the association between BC risk and SNPs, rs3746444 (pre-miR-499), rs12975333 (pre-miR-125a), rs2043556 (miR-605), rs2910164 (pre-miR-146a), and rs4541843 (pri-miR-182).

The human miR-146a gene at locus $5 \mathrm{q} 34$ has been linked with BRCA1/BRCA2 activity. The SNP rs2910164:G>C, located in the middle of the miRNA stem hairpin, leads to a change from a G:U pair to a C:U mismatch in the stem structure of the precursor molecule, altering the expression of mature miR-146a [44]. This SNP has been associated with the risk of various cancers [45,46], and with cancer-specific and ethnicity-dependent effects [23,37].

The variant rs3746444 in the mature miR-499-3p produces a change from an A:U pair to a G:U mismatch in the stem structure of the precursor molecule, leading to an altered processing and expression of the mature transcript [44], and potentially affecting the binding of the target mRNAs to the mature miRNA-3p [44]. miR-499 can target regulation of FOXO4, PDCD4, Sox6, and Rod1 expression [47-49], all of which play important roles in the etiology of various cancers [48]. Many studies have explored the association between the rs3746444:A>G SNP and the susceptibility to BC [44], lung cancer [50], gallbladder cancer [51], squamous cell carcinomas of the head and neck [52], liver cancer [53], and colorectal cancer [54]. Studies on the association between this SNP and BC susceptibility have also shown that rs3746444 has different effects on different populations.

miR-125a is located on chromosome 19q13.41 in the human genome. The identified targets of miR-125a include Lin-28, Lin-41, ERBB2, and ERBB3 mRNAs, all of which are involved in BC tumorigenesis [55-57]. One miRNA profiling study found that mir-125a was downregulated in $B C$ [58]. Other data suggest that 
miR-125 may play an important role in BC pathogenesis [59]. The rs12975333:G>T is located at the eighth nucleotide (+8) within the mature miR-125a. An in vivo analysis demonstrated that this SNP significantly blocks the processing of pri-miRNA to pre-miRNA, and reduces the miRNA-mediated translational suppression [59]. This SNP was also strongly associated with BC tumorigenesis in a Belgian population from Antwerp [38], suggesting that miR-125a likely functions as a tumor suppressor gene in human cancer [38]. However, in other populations, this SNP is monomorphic for the wild-type allele [39].

Several studies have investigated the association between miR-605 rs2043556:T>C and cancer risk. A meta-analysis by $\mathrm{Hu}$ et al. [60], concluded that there was a significant association between the rs2043556 C allele and an overall risk of human cancer. To date, however, only two association studies have been performed to assess the contribution of miR-605 rs2043556 to BC risk [23,31].

Finally, the rs4541843:C>T located in the boundaries of pre-miR-182 (pri-miR-182 region), and is described in the Ensembl genome browser 90 database. While miR-182 is known to be involved in breast carcinogenesis, there are no association studies in the literature regarding the contribution of rs4541843 to BC susceptibility.

This study was designed to evaluate the association of these SNPs rs2910164 in pre-miR-146a, rs4541843 in pri-miR-182, rs3746444 in pre-miR-499, rs12975333 in pre-miR-125a, and rs2043556 in miR-605 with familial BC and early-onset non-familial BC in non-carriers of BRCA1/2 mutations from a South American population.

\section{Materials and Methods}

\subsection{Families}

A total of $440 \mathrm{BC}$ patients belonging to 440 high-risk, BRCA1/2-negative, Chilean families were selected from the files of the Servicio de Salud del Area Metropolitana de Santiago, Corporación Nacional del Cáncer (CONAC), and other private health services in the Metropolitan Region of Santiago. All of the index cases were tested for BRCA1 and BRCA2 mutations, as previously described [61]. Pedigrees were constructed from the index case with the highest probability of carrying a deleterious mutation. None of the families studied met the criteria for other known BC-related syndromes, such as Li-Fraumeni, ataxia-telangiectasia, or Cowden disease.

Table 1 shows the specific characteristics of the families selected according to the inclusion criteria. All of the study families had self-reported Chilean ancestry dating from several generations, confirmed by extensive interviews with several family members from different generations. A total of $16 \%$ of the families (70/440) had bilateral BC cases, 9.0\% (40/440) had both BC and ovarian cancer (OC) cases, and 1.1\% $(5 / 440)$ had male BC cases. The mean age at diagnosis for the BC cases was 42.1 years, and $75.2 \%$ were diagnosed at $<50$ years.

The study was approved by the Institutional Review Board of the University of Chile, School of Medicine (Project code Number 1150117, 1 March 2015). Informed consent was obtained from all of the participants.

Table 1. Inclusion criteria for the families included in this study.

\begin{tabular}{cc}
\hline Inclusion Criteria & Families $\boldsymbol{n}$ \\
\hline Three or more family members with breast and/or ovarian cancer & $121(27.5 \%)$ \\
Two family members with breast and/or ovarian cancer & $148(33.6 \%)$ \\
Single affected individual with breast cancer $\leq$ 35 years of age & $87(19.8 \%)$ \\
Single affected individual with breast cancer between 36 and 50 years of age & $84(19.1 \%)$ \\
Total & $440(100 \%)$ \\
\hline
\end{tabular}

\subsection{Control Population}

The sample of healthy Chilean controls $(n=1048)$ was recruited from CONAC files. Only individuals whose ancestors were Chilean for at least the three previous generations were 
included in the study. The DNA samples were taken from unrelated individuals with no personal or family history of cancer, confirmed by interview performed by a geneticist of our research group. All of the participants provided informed consent for anonymous testing. The DNA samples were obtained in compliance with all of the relevant ethical and legal norms. The control sample was matched to cases for age and socioeconomic strata. Over $90 \%$ of the cases and controls lived in the city of Santiago.

\subsection{Mutation Analysis}

Genomic DNA was extracted from peripheral blood lymphocytes of 440 cases from the selected high-risk families and 1048 controls. The samples were obtained according to the method described by Chomczynski and Sacchi [62].

A complete sequencing study was performed for pre-miR-16 (Chr13:50,048,973-50,049,061), pre-miR-182 (Chr7:129,770,383-129,770,492), pre-miR-192 (Chr11:64,891,137-64,891,246), and pre-miR-146a (Chr5:160,485,352-160,485,450), as well as the boundaries (100 pb to each side) sequence in 99 of the 440 cases. For this analysis, the families were subdivided into those with (a) three or more members with $\mathrm{BC}$ and/or OC ( $43.4 \%)$ and (b) index cases with early-onset BC ( $\leq 35$ years) $(56.6 \%)$. The entire coding sequence and the boundaries of the pre-miRNA(s) sequences were amplified by polymerase chain reaction (PCR). The primers were designed with Primer3 version 0.4.0 [63]. The sequencing was performed using an ABI 3730xl automated fluorescence-based sequencer and BigDye Terminator v3.1 kit (Applied Biosystems, Foster City, CA, USA).

The SNPs, rs3746444 (A>G), rs2910164 (G>C), rs12975333 (A>C), and rs2043556 (T>C), were genotyped using commercially-available TaqMan Genotyping Assays (Thermo Fisher Scientific, Fair Lawn, NJ, USA) (assay ID C_2142612_30, C_15946974_10, C_314447793_10, and C_117374438_10, respectively). A custom TaqMan assay was designed to genotype the SNP rs4541843 (context sequence 5'-ACAGCCAGCGAGGGAAGGGC[C/T]GGCCAATGCTGGACCTGCTGTT-3'). The reaction was performed in a $10 \mu \mathrm{L}$ final volume containing $5 \mathrm{ng}$ of genomic DNA, 1X TaqMan Genotyping Master Mix, and 20X TaqMan SNP Genotyping Assay. The PCR was carried out in a StepOnePlus Real-Time PCR System (Applied Biosystems, Foster City, CA, USA). The thermal cycles were initiated for $10 \mathrm{~min}$ at $95^{\circ} \mathrm{C}$, followed by 40 cycles, each at $92^{\circ} \mathrm{C}$ for $15 \mathrm{~s}$ and $60^{\circ} \mathrm{C}$ for $1 \mathrm{~min}$. Each genotyping run contained control DNA confirmed by sequencing. The alleles were assigned using StepOne software, v2.2 (Applied Biosystems, Foster City, CA, USA). As a quality control, we repeated the genotyping on $\sim 10 \%$ of the samples, and all genotype scoring was performed and checked separately by two reviewers unaware of case-control status.

\subsection{Statistical Analysis}

The Hardy-Weinberg equilibrium assumption was assessed in the control sample using a goodness-of-fit chi-square test (HW Chisq function included in the 'HardyWeinberg'.package v1.4.1 for R, Foundation for Statistical Computing, Vienna, Austria, URL: https:/ /www.r-project.org/). The Fisher's exact test was used to test the association between the genotypes/alleles and the case/control status. The odds ratios (OR) with $95 \%$ confidence intervals (CI) were calculated to estimate the strength of the associations (odds ratio and Fisher's exact test functions were performed using GraphPad Prism v 6.0 for Windows 10, GraphPad Software, La Jolla California, USA, URL: www.graphpad.com) A two-tailed $p$-value $<0.05$ was used as the criterion of significance. The Cochran-Armitage trend test was performed to test the additive genetic effect model (CATT function included in the 'Rassoc' package v 1.03 for R, Foundation for Statistical Computing, Vienna, Austria, URL: https:/ /www.r-project.org/). A chi-square test for the trend was performed to examine the additive combined effects of the risk alleles ('ptrend' was performed in Stata/MP v 13.0 for Windows 10, Unix-StataCorp, College Station, TX, USA; using 'ptrend' package). 


\section{Results}

3.1. Association Study between rs2910164, rs4541843, rs3746444, rs12975333, and rs2043556 with Familial Breast Cancer and Early-Onset Non-Familial Breast Cancer in Non-Carriers of BRCA1/2 Mutations

We analyzed the complete coding sequence and boundaries of pre-miR-16, pre-miR-182, pre-miR-192, and pre-miR-146a in 99 probands who had a strong family history of BC, but were negative for $B R C A 1$ and $B R C A 2$ point mutations, with the aim of identifying new miRNA sequence variations in a Chilean population. No variants were detected in the pre-miR-16 and pre-miR-192 sequences. We identified two variants, rs2910164 (pre-miR-146a) and rs4541843 (pri-miR-182). These two variants and three SNPs from the literature, rs3746444 (pre-miR-499), rs12975333 (pre-miR-125a), and rs2043556 (miR-605), were then analyzed in 440 BRCA1/2-negative cases and 1048 controls. For the case-control analysis, the whole BC sample was subdivided into two subgroups, individuals from families with two or more members with BC and/or OC $(n=269)$ (subgroup A), and individuals with non-familial early-onset BC ( $\leq 50$ years) $(n=171)$ (subgroup B). Subgroup A excludes the subgroup B cases. The genotype distributions and allele frequencies of pre-miR-146a rs2910164:G>C, pri-miR-182 rs4541843:C>T, pre-miR-499 rs3746444:A>G, pre-miR-125a rs12975333:G>T, and miR-605 rs2043556:T>C are shown in Table 2 for the whole patient group and subgroups vs. the controls. The observed genotype frequencies for three of the five polymorphisms were in Hardy-Weinberg equilibrium in the controls ( $p=0.86$ for rs2910164:G>C, $p=0.83$ for rs3746444:A $>\mathrm{G}$, and $p=0.90$ for rs12975333), while the $p$-values for the SNPs rs4541843:C $>$ T and rs2043556:T $>C$ were 0.03 and $<10^{-4}$, respectively.

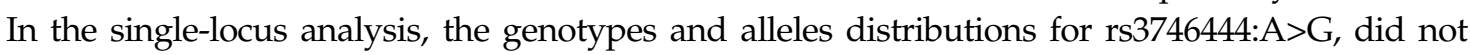
differ significantly between cases and controls, in either the whole-group or subgroup analysis $(p>$ 0.05). The genotype frequencies of rs2910164:G>C in the 99 BRCA1/2-negative probands from high-risk families were $52.7 \% \mathrm{G} / \mathrm{G}, 39.4 \% \mathrm{G} / \mathrm{C}$ and 7.9\% C/C. For the case-control analysis of rs2910164:G>C, the genotypes and alleles distributions did not differ significantly between cases and controls, in either the whole-group or subgroup analysis $(p>0.05)$. For rs12975333:G>T, the frequency of the wild-type allele $(\mathrm{G})$ was 0.996 in controls and 0.995 in cases, and the frequency of allele T was 0.004 in controls and 0.005 in cases. Therefore, the $\mathrm{T}$ allele was extremely rare and practically monomorphic in this Chilean population.

The rs2043556:T>C is located in pre-miR-605. The minor allele frequency (MAF) (allele C) was significantly lower in the whole sample $(0.32)$ and in the subgroup A (0.31) vs. controls $(0.37)(\mathrm{OR}=0.8$ [95\% CI 0.6-0.9] $p=0.01$ and $\mathrm{OR}=0.7$ [95\% CI 0.6-0.9] $p=0.01$, respectively). This result indicates that the $\mathrm{C}$ allele is associated with a protective effect against $\mathrm{BC}$ risk. We also observed a protective effect for the $\mathrm{C}$-allele carriers $(\mathrm{T} / \mathrm{C}+\mathrm{C} / \mathrm{C})$ in the whole sample $\left(\mathrm{OR}=0.6[95 \% \mathrm{CI} 0.4-0.7], p<10^{-4}\right)$, in subgroup $\mathrm{A}\left(\mathrm{OR}=0.6[95 \% \mathrm{CI} 0.4-0.8] p<10^{-4}\right)$, and in single cases diagnosed at $\leq 50$ years of age (subgroup $\left.\mathrm{B}\right)$ $(\mathrm{OR}=0.6$ [95\% CI 0.5-0.9] $p=0.02)$. We also assessed for a protective effect of rs2043556 in according to number of BC cases in the family (Table 3). No protective effect was found for rs2043556 in the families with two $\mathrm{BC} / \mathrm{OC}$ cases. However, the $\mathrm{BC}$ risk was significantly decreased in the $\mathrm{C}$-allele carriers with three or more family members with $\mathrm{BC} / \mathrm{OC}(\mathrm{T} / \mathrm{C}+\mathrm{C} / \mathrm{C})(\mathrm{OR}=0.5[95 \% \mathrm{CI} 0.4-0.9] p=0.006)$. This result indicates that the $\mathrm{C}$-allele was associated with a protective effect in the families with a strong history of $\mathrm{BC}$.

The rs4541843:C>T corresponds to a SNP detected by sequencing in pri-miR-182. This SNP is located

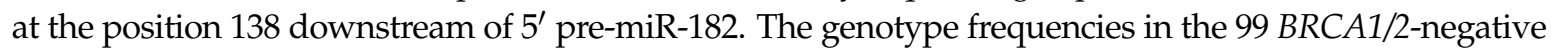
probands from high-risk families were $34.6 \% \mathrm{C} / \mathrm{C}, 42.7 \% \mathrm{C} / \mathrm{T}$, and $22.7 \% \mathrm{~T} / \mathrm{T}$. In the case-control analysis, no significant differences were observed for genotype or allele distribution, for whole group or subgroup $B$ vs. controls $(p>0.05)$. However, in the familial BC cases (subgroup A), the MAF (allele T) was higher in cases than controls (0.46 and 0.41 , respectively, $p=0.01$ ). Furthermore, in subgroup $\mathrm{A}$, the homozygous $\mathrm{T} / \mathrm{T}$ - and T-allele carriers $(\mathrm{C} / \mathrm{T}+\mathrm{T} / \mathrm{T})$ had a significantly increased $\mathrm{BC}$ risk $(\mathrm{OR}=1.5$ [95\% CI 1.0-2.2] $p=0.03$ and $\mathrm{OR}=1.2$ [95\% CI 1.0-1.5] $p=0.01$, respectively) (Table 2), indicating that the $\mathrm{T}$ allele is associated with an increased $\mathrm{BC}$ risk. When we analyzed the effect of the $\mathrm{T}$ allele by the number of $\mathrm{BC}$ cases per family, no association between the rs4541843 and BC risk was found. No associations were observed between this SNP and the early-onset BC (diagnosis $\leq 50$ years of age). It is important to note that is the first association study on this SNP and the risk of a human disease. 
Table 2. Genotype and allelic frequencies of rs3746444, rs2910164, rs12975333, rs2043556, and rs4541843 in BRCA1/2-negative breast cancer cases and controls.

\begin{tabular}{|c|c|c|c|c|c|c|c|c|c|c|}
\hline \multirow[b]{2}{*}{ Genotype or Allele } & \multirow[b]{2}{*}{ Controls $(n=1048)(\%)$} & \multicolumn{3}{|c|}{ All BC Cases $(n=440)$} & \multicolumn{3}{|c|}{ 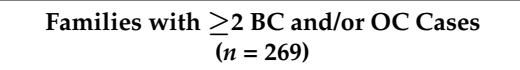 } & \multicolumn{3}{|c|}{$\begin{array}{c}\text { Families with a Single Case, Diagnosis at } \\
\leq 50 \text { Years of Age }(n=171)\end{array}$} \\
\hline & & BC Cases (\%) & $p$-Value ${ }^{a}$ & OR $[95 \% \mathrm{CI}]$ & BC Cases (\%) & $p$-Value ${ }^{\text {a }}$ & OR $[95 \% \mathrm{CI}]$ & BC Cases (\%) & $p$-Value ${ }^{a}$ & OR $[95 \% \mathrm{CI}]$ \\
\hline \multicolumn{11}{|c|}{ rs3746444 (Pre-miR-499) } \\
\hline $\mathrm{A} / \mathrm{A}$ & 772 (73.7) & $319(72.5)$ & - & 1.0 (Ref) & 198 (73.6) & - & 1.0 (Ref) & $121(70.8)$ & - & 1.0 (Ref) \\
\hline $\mathrm{A} / \mathrm{G}$ & 254 (24.2) & $111(25.2)$ & 0.6 & $1.0[0.8-1.3]$ & $64(23.8)$ & 0.9 & $0.9[0.7-1.3]$ & 47 (27.5) & 0.3 & $1.1[0.8-1.7]$ \\
\hline $\mathrm{G} / \mathrm{G}$ & $22(2.1)$ & $10(2.3)$ & 0.8 & $1.1[0.5-2.3]$ & $7(2.6)$ & 0.6 & $1.2[0.5-2.9]$ & $3(1.7)$ & 1.0 & $0.8[0.2-2.9]$ \\
\hline $\mathrm{A} / \mathrm{G}+\mathrm{G} / \mathrm{G}$ & $276(26.3)$ & $121(27.5)$ & 0.6 & $1.0[0.8-1.3]$ & $71(26.4)$ & 1.0 & $1.0[0.7-1.3]$ & $50(29.2)$ & 0.4 & $1.1[0.8-1.6]$ \\
\hline Allele A & $1798(85.8)$ & 749 (85.1) & - & 1.0 (Ref) & 460 (85.5) & - & 1.0 (Ref) & $289(84.5)$ & 0.4 & $\begin{array}{l}1.1[0.0-1.0] \\
1.0 \text { (Ref) }\end{array}$ \\
\hline Allele G & 298 (14.2) & $131(14.9)$ & 0.6 & $1.0[0.8-1.3]$ & $78(14.5)$ & 0.9 & $1.0[0.7-1.3]$ & $53(15.5)$ & 0.5 & $1.1[0.8-1.5]$ \\
\hline \multicolumn{11}{|c|}{ rs2910164 (Pre-miR-146a) } \\
\hline $\mathrm{G} / \mathrm{G}$ & $561(53.5)$ & $236(53.6)$ & - & 1.0 (Ref) & 149 (55.4) & - & 1.0 (Ref) & $87(50.9)$ & - & 1.0 (Ref) \\
\hline $\mathrm{G} / \mathrm{C}$ & 410 (39.1) & 165 (37.5) & 0.7 & $0.9[0.7-1.1]$ & 101 (37.5) & 0.6 & $0.9[0.6-1.2]$ & $64(37.4)$ & 1.0 & $1.0[0.7-1.4]$ \\
\hline $\mathrm{C} / \mathrm{C}$ & 77 (7.4) & $39(8.9)$ & 0.3 & $1.2[0.7-1.8]$ & 19 (7.1) & 0.8 & $0.9[0.5-1.5]$ & $20(11.7)$ & 0.06 & $1.6[0.9-2.8]$ \\
\hline $\mathrm{G} / \mathrm{C}+\mathrm{C} / \mathrm{C}$ & 487 (46.5) & $204(46.4)$ & 1.0 & $0.9[0.7-1.2]$ & $120(44.6)$ & 0.6 & $0.9[0.7-1.2]$ & $84(49.1)$ & 0.5 & $1.1[0.8-1.5]$ \\
\hline Allele G & 1532 (73.1) & 637 (72.4) & - & 1.0 (Ref) & 399 (74.2) & - & 1.0 (Ref) & $238(69.6)$ & - & 1.0 (Ref) \\
\hline Allele C & $564(26.9)$ & $243(27.6)$ & 0.7 & $1.0[0.8-1.2]$ & $139(25.8)$ & 0.6 & $0.9[0.7-1.1]$ & $104(30.4)$ & 0.2 & $1.1[0.9-1.5]$ \\
\hline \multicolumn{11}{|c|}{ rs12975333 (Pre-miR-125a) } \\
\hline G/G & $1040(99.2)$ & 436 (99.1) & - & 1.0 (ref) & 267 (99.3) & - & 1.0 (ref) & $169(98.8)$ & - & 1.0 (ref) \\
\hline $\mathrm{G} / \mathrm{T}$ & $8(0.8)$ & $4(0.9)$ & 0.7 & $1.1[0.3-3.9]$ & $2(0.7)$ & 0.2 & $1.9[0.5-6.5]$ & $2(1.2)$ & 0.6 & $1.5[0.3-7.3]$ \\
\hline $\mathrm{T} / \mathrm{T}$ & 0 & 0 & - & 1.10 .0 .1 & 0 & - & - & 0 & - & \\
\hline $\mathrm{G} / \mathrm{T}+\mathrm{T} / \mathrm{T}$ & $8(0.8)$ & $4(0.9)$ & 0.7 & $1.1[0.3-3.9]$ & $2(0.7)$ & 0.2 & $1.9[0.5-6.5]$ & $2(1.2)$ & 0.6 & $1.5[0.3-7.3]$ \\
\hline Allele G & $2088(99.6)$ & 876 (99.5) & - & 1.0 (ref) & $536(99.6)$ & - & 1.0 (ref) & $340(99.4)$ & - & 1.0 (ref) \\
\hline Allele T & $8(0.4)$ & $4(0.5)$ & 0.7 & $1.1[0.3-3.9]$ & $2(0.4)$ & 0.2 & $1.9[0.5-6.5]$ & $2(0.6)$ & 0.6 & $1.5[0.3-7.3]$ \\
\hline \multicolumn{11}{|c|}{ rs2043556 (miR-605) } \\
\hline$T / T$ & 376 (35.9) & $208(47.3)$ & - & 1.0 (ref) & $128(47.6)$ & - & 1.0 (ref) & $80(46.8)$ & - & 1.0 (ref) \\
\hline $\mathrm{T} / \mathrm{C}$ & $571(54.5)$ & $182(41.3)$ & $<10^{-4}$ & $0.5[0.4-0.7]$ & 115 (42.7) & 0.0003 & $0.5[0.4-0.7]$ & $67(39.2)$ & 0.0009 & $0.5[0.3-0.7]$ \\
\hline $\mathrm{C} / \mathrm{C}$ & $101(9.6)$ & $50(11.4)$ & 0.6 & $0.8[0.6-1.3]$ & $26(9.7)$ & 0.2 & $0.7[0.5-1.2]$ & $24(14.0)$ & 0.6 & $1.1[0.6-1.8]$ \\
\hline $\mathrm{T} / \mathrm{C}+\mathrm{C} / \mathrm{C}$ & $672(64.1)$ & $232(52.7)$ & $<10^{-4}$ & $0.6[0.4-0.7]$ & $141(52.4)$ & 0.0006 & $0.6[0.4-0.8]$ & $91(53.2)$ & 0.02 & $0.6[0.5-0.9]$ \\
\hline Allele T & $1323(63.1)$ & $598(68.0)$ & - & 1.0 (ref) & $371(69.0)$ & - & 1.0 (ref) & $227(66.4)$ & - & 1.0 (ref) \\
\hline Allele C & $773(36.9)$ & $282(32.0)$ & 0.01 & $0.8[0.6-0.9]$ & $167(31.0)$ & 0.01 & $0.7[0.6-0.9]$ & $115(33.6)$ & 0.4 & $0.9[0.7-1.1]$ \\
\hline \multicolumn{11}{|c|}{ rs4541843 (Pri-miR-182) } \\
\hline $\mathrm{C} / \mathrm{C}$ & $386(36.8)$ & $150(34.1)$ & - & 1.0 (Ref) & $81(30.1)$ & - & 1.0 (ref) & $69(40.4)$ & - & 1.0 Ref \\
\hline $\mathrm{C} / \mathrm{T}$ & $473(45.1)$ & 205 (46.6) & 0.4 & $1.1[0.8-1.4]$ & $127(47.2)$ & 0.1 & $1.2[0.9-1.7]$ & $78(45.6)$ & 0.6 & $0.9[0.6-1.3]$ \\
\hline $\mathrm{T} / \mathrm{T}$ & 189 (18.1) & 85 (19.3) & 0.4 & $1.5[0.8-1.5]$ & $61(22.7)$ & 0.03 & $1.5[1.0-2.2]$ & $24(14.0)$ & 0.1 & $0.7[0.4-1.1]$ \\
\hline $\mathrm{C} / \mathrm{T}+\mathrm{T} / \mathrm{T}$ & $662(63.2)$ & $290(65.9)$ & 0.3 & $1.1[0.8-1.4]$ & $188(69.9)$ & 0.04 & $1.3[1.0-1.8]$ & $102(59.6)$ & 0.3 & $0.8[0.6-1.1]$ \\
\hline Allele C & 1245 (59.4) & 505 (57.4) & - & 1.0 (Ref) & 289 (53.7) & - & 1.0 (ref) & 216 (63.2) & - & 1.0 (Ref) \\
\hline Allele T & 851 (40.6) & 375 (42.6) & 0.3 & $1.0[0.9-1.2]$ & 249 (46.3) & 0.01 & $1.2[1.0-1.5]$ & $126(36.8)$ & 0.2 & $0.8[0.6-1.0]$ \\
\hline
\end{tabular}

BC—breast cancer; OC—ovarian cancer; OR—odds ratio; CI—confidence interval; Ref—Reference. ${ }^{\text {a }}$ Fisher's exact test. $p<0.05$ statistically significant. 
Table 3. Genotype and allelic frequencies of rs2043556 and rs4541843 according the number of BC cases in the families in BRCA1/2-negative breast cancer cases and controls.

\begin{tabular}{|c|c|c|c|c|c|c|c|}
\hline \multirow[b]{2}{*}{ Genotype or Allele } & \multirow[b]{2}{*}{ Controls $(n=1048)(\%)$} & \multicolumn{3}{|c|}{ Families with 2 BC and/or OC Cases $(n=148)$} & \multicolumn{3}{|c|}{ Families with $\geq 3$ BC and/or OC Cases $(n=121)$} \\
\hline & & BC Cases $(\%)$ & $p$-Value ${ }^{a}$ & OR $[95 \% \mathrm{CI}]$ & BC Cases (\%) & $p$-Value ${ }^{a}$ & OR $[95 \% \mathrm{CI}]$ \\
\hline \multicolumn{8}{|c|}{ rs2043556 (miR-605) } \\
\hline $\mathrm{T} / \mathrm{T}$ & $376(35.9)$ & $67(45.3)$ & - & 1.0 (Ref) & $61(50.4)$ & - & 1.0 (Ref) \\
\hline $\mathrm{T} / \mathrm{C}$ & $571(54.5)$ & $68(45.9)$ & 0.08 & $0.7[0.5-1.0]$ & $47(38.9)$ & 0.003 & $0.5[0.4-0.8]$ \\
\hline $\mathrm{C} / \mathrm{C}$ & $101(9.6)$ & $13(8.8)$ & 0.3 & $0.7[0.4-1.4]$ & $13(10.7)$ & 0.5 & $0.7[0.4-1.5]$ \\
\hline $\mathrm{T} / \mathrm{C}+\mathrm{C} / \mathrm{C}$ & $672(64.1)$ & $81(54.7)$ & 0.06 & $0.7[0.5-1.0]$ & $60(49.6)$ & 0.006 & $0.5[0.4-0.9]$ \\
\hline Allele T & $1323(63.1)$ & $202(68.2)$ & - & 1.0 (Ref) & $169(69.8)$ & - & 1.0 (Ref) \\
\hline Allele C & 773 (36.9) & $94(31.8)$ & 0.1 & 0.8 [0.6-1.0] & $73(30.2)$ & 0.06 & 0.7 [0.5-1.0] \\
\hline \multicolumn{8}{|c|}{ rs4541843 (Pri-miR-182) } \\
\hline $\mathrm{C} / \mathrm{C}$ & $386(36.8)$ & $45(30.4)$ & - & 1.0 (Ref) & $36(29.8)$ & - & 1.0 (Ref) \\
\hline $\mathrm{C} / \mathrm{T}$ & $473(45.1)$ & $70(47.3)$ & 0.2 & 1.2 [0.8-1.8] & $57(47.1)$ & 0.2 & 1.2 [0.8-1.9] \\
\hline $\mathrm{T} / \mathrm{T}$ & $189(18.1)$ & $33(22.3)$ & 0.1 & $1.4[0.8-2.4]$ & $28(23.1)$ & 0.09 & $1.5[0.9-2.6]$ \\
\hline $\mathrm{C} / \mathrm{T}+\mathrm{T} / \mathrm{T}$ & $662(63.2)$ & $103(69.6)$ & 0.1 & 1.3 [0.9-1.9] & $85(70.2)$ & 0.1 & $1.3[0.9-2.0]$ \\
\hline Allele C & 1245 (59.4) & $160(54.1)$ & - & 1.0 (Ref) & $129(53.3)$ & - & 1.0 (Ref) \\
\hline Allele T & $851(40.6)$ & $136(45.9)$ & 0.09 & 1.2 [0.9-1.5] & $113(46.7)$ & 0.07 & 1.2 [0.9-1.6] \\
\hline
\end{tabular}

BC—breast cancer; OC—ovarian cancer; OR—odds ratio; CI—confidence interval; Ref-Reference. ${ }^{\text {a }}$ Fisher's exact test. $p<0.05$ Statistically significant. 
3.2. Combined Effect between TOX3 rs3803662-T and pri-miR-182 rs4541843-T Alleles with Breast Cancer Risk

In a previous publication, our group showed that TOX3 rs3803662: $\mathrm{C}>\mathrm{T}$ was significantly associated with an increased BC risk in familial BC [12]. As TOX3 rs3803662-T and pri-miR-182 rs4541843-T were associated with an increased BC risk, we considered these two variants to be risk alleles. Moreover, TOX3 mRNA is a target of miR-182 [64]. Therefore, we evaluated the combined effect of these variants. For the analysis, the subjects were divided into five groups based on number of risk alleles (subjects with 0 [group 1], one [group 2], two [group 3], three [group 4], or four [group 5] risk alleles). As shown in Table 4, the distribution of the combined genotypes in the whole patient group and in subgroup A significantly differed from the controls ( $p=0.005$ and 0.0001 , respectively), and the BC risk increased in a dose-dependent manner in the whole sample, and in subgroup A, with the number of risk alleles ( $p$-trend $=0.0005$ and $<10^{-4}$, respectively). No additive effect was observed for early-onset BC (diagnosis $\leq 50$ years of age). We also analyzed this additive effect within cases with a family history of $\mathrm{BC}$, according to the number of BC cases per family (Table 5). An additive effect was observed in the families with two BC/OC cases and the families with the strongest history of $B C$ ( $p$-trend $=0.0001$ and 0.001 , respectively). These results indicate an additive effect of TOX3 rs3803662-T and pri-miR-182 rs4541843-T on BC risk. 
Table 4. Combined effects of rs3803662 (TOX3) and rs4541843 (pri-miR-182) on the risk of breast cancer.

\begin{tabular}{|c|c|c|c|c|c|c|c|c|c|c|}
\hline \multirow{2}{*}{ Number of Risk Alleles (a) } & \multirow{2}{*}{ Controls $(n=1048)(\%)$} & \multicolumn{3}{|c|}{ All BC Cases $(n=440)$} & \multicolumn{3}{|c|}{ 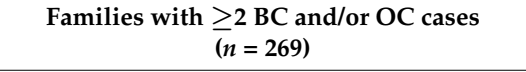 } & \multicolumn{3}{|c|}{$\begin{array}{c}\text { Families with a Single Case, Diagnosis at } \\
\leq 50 \text { Years of Age }(n=171)\end{array}$} \\
\hline & & BC Cases (\%) & OR $[95 \% \mathrm{CI}]$ & $p$-Value ${ }^{(b)}$ & BC Cases (\%) & OR $[95 \% \mathrm{CI}]$ & $p$-Value ${ }^{(\mathrm{b})}$ & BC Cases $(\%)$ & OR $[95 \% \mathrm{CI}]$ & $p$-Value ${ }^{(b)}$ \\
\hline 0 risk alleles & 153 (14.6) & 49 (11.1) & 1.0 (Ref) & - & $22(8.2)$ & 1.0 (Ref) & - & $27(15.8)$ & 1.0 (Ref) & - \\
\hline 1 risk allele & 381 (36.4) & $128(29.1)$ & $1.0[0.7-1.5]$ & 0.8 & $73(27.1)$ & $1.3[0.7-2.2]$ & 0.3 & $55(32.2)$ & $0.8[0.4-1.3]$ & 0.4 \\
\hline 3 risk alleles & 153 (14.6) & $79(18)$ & $1.6[1.0-2.4]$ & 0.02 & $57(21.2)$ & $2.5[1.5-4.4]$ & 0.0006 & $22(12.9)$ & $0.8[0.4-1.4]$ & 0.5 \\
\hline 4 risk alleles & $25(2.4)$ & $16(36)$ & $1.9[0.9-3.8]$ & 0.08 & $12(4.5)$ & $3.2[1.4-7.2]$ & 0.006 & $4(2.3)$ & $0.8[0.2-2.6]$ & 1.0 \\
\hline$p$-trend $(\mathrm{c})$ & & & & 0.0005 & & & $<10^{-4}$ & & & 0.9755 \\
\hline Global $p^{\text {(d) }}$ & & & & 0.005 & & & 0.0001 & & & 0.6970 \\
\hline
\end{tabular}

(b) Fisher's exact test. (c) Chi-test for trend. (d) $\mathrm{Chi}$-squared test for independence. $\mathrm{BC}$-breast cancer; OC—ovarian cancer; OR—odds ratios; $\mathrm{CI}$-confidence

$p \leq 0.05$ statistically significant.

Table 5. Combined effects of rs38033662 (TOX3) and rs4541843 (pri-miR-182) on the risk of breast cancer according the number of BC cases in the families.

\begin{tabular}{|c|c|c|c|c|c|c|c|}
\hline \multirow{2}{*}{ Number of Risk Alleles (a) } & \multirow{2}{*}{ Controls $(n=1048)(\%)$} & \multicolumn{3}{|c|}{ Families with Two BC and/or OC Cases $(n=148)$} & \multicolumn{3}{|c|}{ Families with $\geq 3$ BC and/or OC Cases $(n=121)$} \\
\hline & & BC Cases $(\%)$ & OR $[95 \% \mathrm{CI}]$ & $p$-Value ${ }^{(b)}$ & BC Cases $(\%)$ & OR $[95 \% \mathrm{CI}]$ & $p$-Value ${ }^{(b)}$ \\
\hline 0 risk alleles & $153(14.6)$ & $10(6.8)$ & 1.0 (Ref) & - & $12(8.1)$ & 1.0 (Ref) & - \\
\hline 1 risk allele & $381(36.4)$ & 29 (19.6) & $1.1[0.5-2.4]$ & 0.8 & 44 (29.7) & $1.4[0.7-2.8]$ & 0.2 \\
\hline 2 risk alleles & $336(32.1)$ & $47(31.8)$ & $2.1[1.0-4.3]$ & 0.03 & $58(39.2)$ & $2.2[1.1-4.2]$ & 0.01 \\
\hline 3 risk alleles & $153(14.6)$ & $30(20.3)$ & $3.0[1.4-6.3]$ & 0.003 & $27(18.2)$ & $2.2[1.0-4.6]$ & 0.02 \\
\hline 4 risk alleles & $25(2.4)$ & $5(3.4)$ & $2.9[0.9-9.3]$ & 0.06 & $7(4.7)$ & $3.4[1.2-9.5]$ & 0.02 \\
\hline$p$-trend ${ }^{(c)}$ & & & & 0.0001 & & & 0.001 \\
\hline Global $p^{(\mathrm{d})}$ & & & & 0.001 & & & 0.02 \\
\hline
\end{tabular}

(a) 0 risk allele: $\mathrm{C} / \mathrm{C}+\mathrm{C} / \mathrm{C} ; 1$ risk allele: $\mathrm{C} / \mathrm{C}+\mathrm{C} / \mathrm{T}, \mathrm{C} / \mathrm{T}+\mathrm{C} / \mathrm{C} ; 2$ risk alleles: $\mathrm{C} / \mathrm{C}+\mathrm{T} / \mathrm{T}, \mathrm{T} / \mathrm{T}+\mathrm{C} / \mathrm{C}, \mathrm{C} / \mathrm{T}+\mathrm{C} / \mathrm{T} ; 3$ risk alleles: $\mathrm{C} / \mathrm{T}+\mathrm{T} / \mathrm{T}, \mathrm{T} / \mathrm{T}+\mathrm{C} / \mathrm{T} ; 4$ risk alleles: $\mathrm{T} / \mathrm{T}+\mathrm{T} / \mathrm{T}$.

(b) Fisher's exact test. ${ }^{(c)}$ Chi-test for trend. ${ }^{(d)}$ Chi-squared test for independence. BC—breast cancer; OC—ovarian cancer; OR—odds ratios, $\mathrm{CI}-$ confidence interval; Ref-Reference.

$p \leq 0.05$ Statistically significant. 


\section{Discussion}

Currently, there is consensus that the BRCA1 and BRCA2 mutations are responsible for an average of only $16 \%$ of the risk for familial breast and ovarian cancers [3,5]. Consequently, there is an intensive search for additional targets.

The miRNAs are a class of endogenous, non-coding, single-stranded RNAs involved in many molecular pathways and biological processes, including the development, apoptosis, differentiation, proliferation, and immune response [65]. Many miRNAs have been implicated in various human diseases, and it has been shown that miRNAs are aberrantly expressed or mutated in many cancers. SNPs are the most common form of variation present in the human genome. The SNPs in the miRNA regions can alter the genetic expression, processing, and maturation, as well as the target binding affinity and specificity $[23,66]$. Therefore, many epidemiological studies have examined the associations between the miRNA SNPs and BC susceptibility [22]. It is important to note that genetic variability is ethnicity-specific. To date, most miRNA SNP studies have been performed in cases from European, Asian, Arab, or Jewish populations, mainly in sporadic BC. In contrast, the publications regarding the role of the miRNA variations in $B C$ susceptibility among Latin-American populations are very scarce. In the present study, we evaluated the impact of the miRNA SNPs on familial and early-onset BC in Chilean families negative for BRCA1/2 point mutations. To this end, we performed a case-control study to examine the association between the BC risk and rs2910164 in pre-miR-146a, rs4541843 in pri-miR-182, rs3746444 in pre-miR-499, rs12975333 in pre-miR-125a, and rs2043556 in pre-miR-605.

Our data do not support an association between rs2910164:G>C or rs3746444:A>G and BC risk. The SNP rs2910164:G>C resides within miR-146a, a microRNA that binds to the $3^{\prime}$ untranslated region of the BRCA1 transcript [43] and negatively regulates expression of this gene [27]. There have been a number of studies on rs2910164 in populations of various ethnicities, but the results are controversial $[24,25,27,43,67-69]$. Shen et al. (2008) [43] reported in US population that $B R C A 1 / 2$-negative $\mathrm{BC} / \mathrm{OC}$ cases with $\mathrm{G} / \mathrm{C}-\mathrm{C} / \mathrm{C}$ genotypes were significantly younger at diagnosis than those with the G/G genotype; nevertheless, the ethnicity of the US population used in this study was not specified. This association was not confirmed in a study by Catucci et al. (2010) [24], who reported no association between rs2910164 with BC risk or the age of onset in BRCA1/2-negative BC patients from Germany and Italy. On the other hand, Pastrello et al. (2010) [25] reported that the SNP miR-146a rs2910164 had a potential impact on the age of onset in an Italian population of BRCA1/2-negative familial BC/OC patients. In a North Indian population, Bansal et al. (2014) [68] demonstrated that the miR-146a G/G (rs2910164) polymorphism was associated with reduced genetic susceptibility to BC. However, a multivariate analysis showed that this SNP was associated with an increased BC risk in postmenopausal females. In a Chinese population, the rs2910164 G/G and C/G-G/G genotypes were associated with an increased BC risk in the postmenopausal BC cases with no familial history of BC [69]. In an Iranian population, the rs2910164 polymorphism was not significantly associated with the occurrence of BC. Several meta-analyses that included the rs2910164:G>C polymorphism were published between 2011 and 2017. Of these, two meta-analyses reported that rs2910164 contributed to BC susceptibility in a Caucasian population [29,70]. The other five meta-analyses showed that rs2910164 was not associated with BC susceptibility in Caucasians or Asians $[23,37,44,71,72]$. The majority of authors suggest that the oncogenic mechanisms are markedly influenced by specific genetic backgrounds across populations. The contemporary Chilean population stems from the admixture of Amerindian people with the Spanish settlers in the sixteenth and seventeenth centuries. Later (nineteenth-century) migrations of Germans, Italians, Arabs, and Croatians had only a minor impact on the general population (accounting for no more than $4 \%$ of the total population), with effects restricted to the specific locations of the country where these immigrants settled [73]. The relationships among ethnicity, Amerindian admixture, genetic markers, and socioeconomic strata in Chile have been studied extensively [74,75]. The SNP rs3746444, located at the 3p mature miRNA-499, was also found to have no association with BC risk in our study. This polymorphism involves an $\mathrm{A}>\mathrm{G}$ nucleotide substitution, leading to altered processing and the 
expression of the mature transcript [76]. The analyses of rs3746444 polymorphisms in BC patients have shown mixed results. Several studies have reported that rs3746444 was associated with an increased BC risk in Iranian [34,67,77] and Chinese populations [69,78]. In contrast, other studies found no association between rs3746444 and BC risk in Caucasian (German and Italian) [24] or North Indian populations [68]. In addition, all five meta-analyses published to date have found that rs3746444 is associated with an increased BC risk in Asians, but not Caucasians [23,44,72,76,79]. Given the European and Native American ancestry estimates for Chileans as $52 \%$ and $44 \%$ on average, respectively, these results could explain the lack of association of rs3746444 with BC risk in this group [80].

The variant rs12975333:G>T is located in the seed region of the mature miRNA-125a. The T allele reportedly blocks the processing of pri-miRNA to the pre-miRNA precursor. This variation is extremely rare, having been detected in only one of 1200 individuals from diverse ethnic backgrounds in a study by the Centre d'Etude du Polymorphisme Humain [38]. Li et al. (2009) [38] showed that rs12975333-T was strongly associated with BC risk in a Belgian population from Antwerp. These authors found that while $8.3 \%$ of the $\mathrm{BC}$ cases were T-allele carriers, this risk allele was not present in any of the 192 controls from the general population in the Antwerp area or the 587 Caucasian controls collected in the United States [38]. This SNP was also monomorphic for the G allele in a sample of 340 healthy individuals from Catalonia (in northeast Spain) [81]. Peterlongo et al. (2011) [39] showed that rs12975333 was monomorphic in 4114 controls from Germany, Italy, Australia, and Spain (Madrid). Moreover, the authors suggested that very few BC cases, if any, were attributable to rs12975333 in the populations studied. Our results also indicate that rs12975333 is extremely rare, if not absent, in the BC cases and controls from a Chilean population. Therefore, we were unable to estimate the association between rs12975333 and BC risk.

Several studies have investigated the association between miR-605 rs2043556:T>C and cancer risk [82]. Specifically, the miR-605 C allele was associated with an increased risk of bladder cancer in a Caucasian population [60], and in gastrointestinal cancer, the $C$ allele was significantly less common in the controls vs. cancer patients in an Asian population [31]. However, rs2043556-C significantly decreased the oral squamous cell carcinoma risk in a Chinese population [82]. Only one article and one meta-analysis have evaluated the association between rs2043556 and BC risk. In a Chinese population, no significant association with BC risk was observed [31], while the meta-analysis by Chen et al. (2014) [23], reported that the miR-605 rs2043556 C/C genotype may increase the BC susceptibility in an Asian population. Because all of the participants in this meta-analysis were Asian, additional case-control studies, especially in non-Asian populations, are necessary to validate the finding. Our results showed that the rs2043556 C allele was associated with a protective effect in the BRCA1/2-negative Chilean women with a strong family history of BC or non-familial, early-onset BC. These results are contradictory to the results obtained in Asians. Therefore, given that the Chilean population is $\sim 52 \%$ Caucasian and $\sim 44 \%$ Native Amercican, studies in other population are needed. One important issue to consider is that the genotype distribution of rs2043556 is in a Hardy-Weinberg disequilibrium, which could distort the results. The possibility that different selective factors may directly or indirectly alter the association between rs2043556 and BC risk cannot be discarded.

miR-182 is one of three miRNAs in the miR-183/182/96 cluster, located in a $5-\mathrm{Kb}$ region of human chromosome 7q32.2 [83]. Several studies have confirmed that the members of the miR-182 cluster are abnormally expressed in some cancers and other human diseases [84]. This cluster, and specifically miR-182, is highly expressed in many BC subtypes. This molecule functions as an onco-miRNA, promoting the proliferation and migration of BC cells [85]. With respect to miR-182, Moskwa et al. (2011) [41] reported that the Argonaute/miR-182 complex associates selectively with the BRCA1 transcript and that miR-182 downregulates the BRCA1 expression. Therefore, miR-182 overexpression reduces the BRCA1 protein levels and impairs the homologous recombination-mediated repair. In addition, consistent with a BRCA1-deficiency phenotype, miR-182-overexpressing breast tumor cells are hypersensitive to the inhibitors of poly (ADP-ribose) polymerase I (PARP1) [41]. Krishman et al. (2013) [86] showed that miR-182 is overexpressed in 
several molecular subtypes of BC. This author then experimentally validated that miR-182 mediates the disruption of homologous recombination (HR), as a consequence of its ability to target multiple components of that pathway [86]. Other targets of miR-182 include the transcription factor TOX3 mRNA; Nibrin NBN mRNA, which is a gene member of the MRE11/RAD50 double-strand break repair complex; and LIM and SH3 domain protein 1 (LASP1) mRNA. Therefore, miR-182 may participate in the regulation of DNA double-strand break repair and estrogen receptor-mediated gene expression, by regulating the NBN and TOX3 expression. Moreover, miR-182 may also influence the nodal positivity and tumor size of breast carcinomas by regulating LASP1 expression [64]. The SNP rs4541843:C>T is located in pre-miR-182. This SNP is described in the Ensembl genome browser 90 database; nevertheless, there are no studies in the literature assessing the association of rs4541843:C $>\mathrm{T}$ with any human disease. Here, we performed a case-control study on rs4541843:C $>\mathrm{T}$, showing that the $\mathrm{T}$ allele is associated with an increased $\mathrm{BC}$ risk. In addition, homozygous $\mathrm{T} / \mathrm{T}-$ and T-allele carriers $(C / T+T / T)$ had a significantly increased $B C$ risk among BRCA1/2-negative familial BC cases. Given the known roles of miR-182, it could be hypothesized that rs4541843-T induces miR-182 overexpression, reducing the BRCA1 protein levels by altering the pathways involved in maintaining the genomic stability. Thus, the association of rs4541843-T with an increased BC risk in the BRCA1/2-negative $B C$ patients could be a consequence of reduced BRCA1 protein levels. Studies in other populations are needed to confirm this assertion, as this is the first association study on rs4541843:C $>\mathrm{T}$ and BC risk.

In a previous publication, our group described an association between the TOX3 rs3803662:C $>\mathrm{T}$ and risk of familial BC. In this study, we showed that rs4541843-T, located in the boundaries of pre-miR-182 (pri-miR-182 region), is also associated with an increased BC risk. Considering that the transcription factor TOX3 mRNA is a target of miR-182 [64], we evaluated the combined effects of the TOX3 rs3803662-T and pri-miR-182 rs4541843-T, and constructed a genetic score based on the number of risk alleles. A dose-response association was observed for familial BC. The presence of four risk alleles was associated with a 3.2-fold increased risk of familial $B C$ compared with the zero risk alleles. miRNA-182 is an onco-miRNA in BC $[85,87]$ that regulates the expression of $B R C A 1, N B N$, LASP1, and TOX3, and other genes [64]. miR-182 is upregulated in BC, increasing the proliferation, migration, and tumorigenesis of BC cells $[87,88]$. TOX3 also encodes a protein that plays a pivotal role in calcium-dependent transcription, as a transcription factor [89]. This gene is located on chromosome 16q12. The loss of heterozygosity $(\mathrm{LOH})$ and the translocations involving the $16 \mathrm{q}$ region are commonly observed in BC [90]. Moreover, TOX3 is expressed in mammary ER+ epithelial cells, and regulates the expression of estrogen receptor-mediated genes [91]. Associations between several TOX3 or nearly TOX3 SNPs and BC susceptibility have been established in European, Asian, African American, and South American populations [12,92-96]. Among these, rs3803662:C>T is the most strongly correlated with disease. Each copy of rs3803662-T is associated with a $20 \%$ increase in BC risk [93]. Riaz et al. (2012) [97], suggested that TOX3 might act as a tumor suppressor gene and that the risk allele rs3803662-T is significantly associated with a reduced TOX3 expression. Furthermore, TOX3 mRNA is a target of miR-182, and miR-182 overexpression reduces the TOX3 endogenous transcript level [64]. Consequently, the presence of the risk alleles from both of the SNPs could produce a more marked decrease in the TOX3 expression. This effect increases with the number of risk alleles, producing a dose-dependent increase in the BC risk. Functional studies are needed to elucidate the biological consequences of rs4541843: $\mathrm{C}>\mathrm{T}$ in breast and other cancers. The potential utility of miR-182 in BC therapy should also be considered. Although our study provides evidence for an association of rs2043556 and rs4541843 with BC risk, certain limitations must be considered. Firstly, the genotype distribution of rs2043556 did not conform to the Hardy-Weinberg expectations, which may distort the results. Secondly, the sample size of the whole group in the present study is sufficient to yield $80 \%$ power; nevertheless, the sample size limits the subgroup analyses. Therefore, these results should be replicated using subgroups with larger sample sizes. 
Author Contributions: S.M. and T.D.M. conceived and designed the experiments; T.D.M., S.M. and F.A.G. carried out the genotyping assays; S.M., V.C., and P.G.-H. performed the statistical analysis; T.D.M. and L.J. analyzed the Sanger sequencing data; J.M.R., F.G., and E.W. selected familial breast cancer cases from the various oncology services; L.J. contributed reagents/materials/analysis tools; S.M. and L.J. wrote the paper. All of the authors reviewed the manuscript.

Funding: Grant Sponsor: Fondo Nacional de Desarrollo Científico y Tecnológico (FONDECYT), Grant Number 1150117.

Acknowledgments: The authors thank the many families who participated in the research studies described in this article. We acknowledge the CONAC Breast Cancer Group: María Teresa Barrios, Angelica Soto, Rossana Recabarren, Leticia García, Karen Olmos, and Paola Carrasco. We would like to thank Lorena Seccia, Felipe Benavides, and Sofia Burattini for their contribution the experimental work.

Conflicts of Interest: The authors declare that the research was conducted in the absence of any commercial or financial relationships that could be construed as a potential conflict of interest. The funders had no role in the design of the study; in the collection, analyses, or interpretation of data; in the writing of the manuscript; and in the decision to publish the results.

Ethical Approval and Informed Consent: This research (code ID \# FONDECYT 1150117) was performed in accordance with the Helsinki Declaration and was approved by the ethics committee of the University of Chile/School of Medicine (Ethics Committee of Research in Humans). Informed consent for this research was conducted under the approval of the ethics committee of the University of Chile/School of Medicine. Both informed and written consent were obtained for all of the participants in the study.

\section{References}

1. Jemal, A.; Siegel, R.; Ward, E.; Hao, Y.; Xu, J.; Thun, M.J. Cancer statistics, 2009. CA Cancer J. Clin. 2009, 59, 225-249. [CrossRef] [PubMed]

2. De Salud, M. Guía Clínica AUGE Cáncer de Mama; Manejo Integral del Cáncer y otros Tumores, Ed.; Ministerio de Salud-Gobierno de Chile: Santiago, Chile, 2015.

3. Stratton, M.R.; Rahman, N. The emerging landscape of breast cancer susceptibility. Nat. Genet. 2008, 40, 17-22. [CrossRef] [PubMed]

4. Couch, F.J.; Hart, S.N.; Sharma, P.; Toland, A.E.; Wang, X.; Miron, P.; Olson, J.E.; Godwin, A.K.; Pankratz, V.S.; Olswold, C.; et al. Inherited mutations in 17 breast cancer susceptibility genes among a large triple-negative breast cancer cohort unselected for family history of breast cancer. J. Clin. Oncol. 2015, 33, 304-311. [CrossRef] [PubMed]

5. Anglian Breast Cancer Study Group. Prevalence and penetrance of BRCA1 and BRCA2 mutations in a population-based series of breast cancer cases. Br. J. Cancer 2000, 83, 1301-1308. [CrossRef] [PubMed]

6. Chandler, M.R.; Bilgili, E.P.; Merner, N.D. A review of whole-exome sequencing efforts toward hereditary breast cancer susceptibility gene discovery. Hum. Mutat. 2016, 37, 835-846. [CrossRef] [PubMed]

7. Leyton, Y.; Gonzalez-Hormazabal, P.; Blanco, R.; Bravo, T.; Fernandez-Ramires, R.; Morales, S.; Landeros, N.; Reyes, J.M.; Peralta, O.; Tapia, J.C.; et al. Association of PALB2 sequence variants with the risk of familial and early-onset breast cancer in a South-American population. BMC Cancer 2015, 15, 30. [CrossRef] [PubMed]

8. Gonzalez-Hormazabal, P.; Reyes, J.M.; Blanco, R.; Bravo, T.; Carrera, I.; Peralta, O.; Gomez, F.; Waugh, E.; Margarit, S.; Ibañez, G.; et al. The BARD1 Cys557Ser variant and risk of familial breast cancer in a South-American population. Mol. Biol. Rep. 2012, 39, 8091-8098. [CrossRef] [PubMed]

9. Gonzalez-Hormazabal, P.; Bravo, T.; Blanco, R.; Valenzuela, C.Y.; Gomez, F.; Wauhg, E.; Peralta, O.; Ortuzar, W.; Reyes, J.M.; Jara, L. Association of common ATM variants with familial breast cancer in a South American population. BMC Cancer 2008, 8, 117. [CrossRef] [PubMed]

10. Gonzalez-Hormazabal, P.; Castro, V.G.; Blanco, R.; Gomez, F.; Peralta, O.; Waugh, E.; Bravo, T.; Reyes, J.M.; Jara, L. Absence of CHEK2 1100delC mutation in familial breast cancer cases from a South American population. Breast Cancer Res. Treat. 2008, 110, 543-545. [CrossRef] [PubMed]

11. Jara, L.; Gonzalez-Hormazabal, P.; Cerceno, K.; Di Capua, G.A.; Reyes, J.M.; Blanco, R.; Bravo, T.; Peralta, O.; Gomez, F.; Waugh, E.; et al. Genetic variants in FGFR2 and MAP3K1 are associated with the risk of familial and early-onset breast cancer in a South-American population. Breast Cancer Res. Treat. 2013, 137, 559-569. [CrossRef] [PubMed] 
12. Elematore, I.; Gonzalez-Hormazabal, P.; Reyes, J.M.; Blanco, R.; Bravo, T.; Peralta, O.; Gomez, F.; Waugh, E.; Margarit, S.; Ibanez, G.; et al. Association of genetic variants at TOX3, 2q35 and 8q24 with the risk of familial and early-onset breast cancer in a South-American population. Mol. Biol. Rep. 2014, 41, 3715-3722. [CrossRef] [PubMed]

13. Mehrgou, A.; Akouchekian, M. The importance of BRCA1 and BRCA2 genes mutations in breast cancer development. Med. J. Islam. Repub. Iran 2016, 30, 369. [PubMed]

14. Rothe, F.; Ignatiadis, M.; Chaboteaux, C.; Haibe-Kains, B.; Kheddoumi, N.; Majjaj, S.; Badran, B.; Fayyad-Kazan, H.; Desmedt, C.; Harris, A.L.; et al. Global microRNA expression profiling identifies miR-210 associated with tumor proliferation, invasion and poor clinical outcome in breast cancer. PLoS ONE 2011, 6, e20980. [CrossRef] [PubMed]

15. Song, F.J.; Chen, K.X. Single-nucleotide polymorphisms among microRNA: Big effects on cancer. Chin. J. Cancer 2011, 30, 381-391. [CrossRef] [PubMed]

16. Lee, R.C.; Feinbaum, R.L.; Ambros, V. The C. elegans heterochronic gene lin-4 encodes small RNAs with antisense complementarity to lin-14. Cell 1993, 75, 843-854. [CrossRef]

17. He, L.; Hannon, G.J. microRNAs: Small RNAs with a big role in gene regulation. Nat. Rev. Genet. 2004, 5, 522-531. [CrossRef] [PubMed]

18. Lewis, B.P.; Burge, C.B.; Bartel, D.P. Conserved seed pairing, often flanked by adenosines, indicates that thousands of human genes are microRNA targets. Cell 2005, 120, 15-20. [CrossRef] [PubMed]

19. Erson, A.E.; Petty, E.M. microRNAs in development and disease. Clin. Genet. 2008, 74, 296-306. [CrossRef] [PubMed]

20. Lu, J.; Getz, G.; Miska, E.A.; Alvarez-Saavedra, E.; Lamb, J.; Peck, D.; Sweet-Cordero, A.; Ebert, B.L.; Mak, R.H.; Ferrando, A.A.; et al. microRNA expression profiles classify human cancers. Nature 2005, 435, 834-838. [CrossRef] [PubMed]

21. Esquela-Kerscher, A.; Slack, F.J. Oncomirs-microRNAs with a role in cancer. Nat. Rev. Cancer 2006, 6, 259-269. [CrossRef] [PubMed]

22. O'Day, E.; Lal, A. microRNAs and their target gene networks in breast cancer. Breast Cancer Res. 2010, 12, 201. [CrossRef] [PubMed]

23. Chen, Q.H.; Wang, Q.B.; Zhang, B. Ethnicity modifies the association between functional microRNA polymorphisms and breast cancer risk: A HuGE meta-analysis. Tumour Biol. 2014, 35, 529-543. [CrossRef] [PubMed]

24. Catucci, I.; Yang, R.; Verderio, P.; Pizzamiglio, S.; Heesen, L.; Hemminki, K.; Sutter, C.; Wappenschmidt, B.; Dick, M.; Arnold, N.; et al. Evaluation of SNPs in miR-146a, miR196a2 and miR-499 as low-penetrance alleles in German and Italian familial breast cancer cases. Hum. Mutat. 2010, 31, E1052-E1057. [CrossRef] [PubMed]

25. Pastrello, C.; Polesel, J.; Della Puppa, L.; Viel, A.; Maestro, R. Association between hsa-miR-146a genotype and tumor age-of-onset in BRCA1/BRCA2-negative familial breast and ovarian cancer patients. Carcinogenesis 2010, 31, 2124-2126. [CrossRef] [PubMed]

26. Yang, R.; Schlehe, B.; Hemminki, K.; Sutter, C.; Bugert, P.; Wappenschmidt, B.; Volkmann, J.; Varon, R.; Weber, B.H.; et al. A genetic variant in the pre-miR-27a oncogene is associated with a reduced familial breast cancer risk. Breast Cancer Res. Treat. 2010, 121, 693-702. [CrossRef] [PubMed]

27. Garcia, A.I.; Cox, D.G.; Barjhoux, L.; Verny-Pierre, C.; Barnes, D.; Antoniou, A.C.; Stoppa-Lyonnet, D.; Sinilnikova, O.M.; Mazoyer, S. The rs2910164:G>C SNP in the MIR146A gene is not associated with breast cancer risk in BRCA1 and BRCA2 mutation carriers. Hum. Mutat. 2011, 32, 1004-1007. [CrossRef] [PubMed]

28. Catucci, I.; Verderio, P.; Pizzamiglio, S.; Bernard, L.; Dall'olio, V.; Sardella, D.; Ravagnani, F.; Galastri, L.; Barile, M.; Peissel, B.; et al. The SNP rs895819 in miR-27a is not associated with familial breast cancer risk in Italians. Breast Cancer Res. Treat. 2012, 133, 805-807. [CrossRef] [PubMed]

29. Lian, H.; Wang, L.; Zhang, J. Increased risk of breast cancer associated with CC genotype of Has-miR-146a Rs2910164 polymorphism in Europeans. PLoS ONE 2012, 7, e31615. [CrossRef] [PubMed]

30. Hu, Z.; Liang, J.; Wang, Z.; Tian, T.; Zhou, X.; Chen, J.; Miao, R.; Wang, Y.; Wang, X.; Shen, H. Common genetic variants in pre-microRNAs were associated with increased risk of breast cancer in Chinese women. Hum. Mutat. 2009, 30, 79-84. [CrossRef] [PubMed]

31. Zhang, M.; Jin, M.; Yu, Y.; Zhang, S.; Wu, Y.; Liu, H.; Chen, B.; Li, Q.; Ma, X.; Chen, K. Associations of miRNA polymorphisms and female physiological characteristics with breast cancer risk in Chinese population. Eur. J. Cancer Care 2012, 21, 274-280. [CrossRef] [PubMed] 
32. Alshatwi, A.A.; Shafi, G.; Hasan, T.N.; Syed, N.A.; Al-Hazzani, A.A.; Alsaif, M.A.; Alsaif, A.A. Differential expression profile and genetic variants of microRNAs sequences in breast cancer patients. PLoS ONE 2012, 7, e30049. [CrossRef] [PubMed]

33. Kontorovich, T.; Levy, A.; Korostishevsky, M.; Nir, U.; Friedman, E. Single nucleotide polymorphisms in miRNA binding sites and miRNA genes as breast/ovarian cancer risk modifiers in Jewish high-risk women. Int. J. Cancer 2010, 127, 589-597. [CrossRef] [PubMed]

34. Kabirizadeh, S.; Azadeh, M.; Mirhosseini, M.; Ghaedi, K.; Tanha, H.M. The SNP rs3746444 within miR-499a is associated with breast cancer risk in Iranian population. J. Cell. Immnother. 2016, 2, 95-97. [CrossRef]

35. Linhares, J.J.; Azevedo, M., Jr.; Siufi, A.A.; de Carvalho, C.V.; Wolgien Mdel, C.; Noronha, E.C.; Bonetti, T.C.; da Silva, I.D. Evaluation of single nucleotide polymorphisms in microRNAs (hsa-miR-196a2 rs11614913 C/T) from Brazilian women with breast cancer. BMC Med. Genet. 2012, 13, 119. [CrossRef] [PubMed]

36. Morales, S.; Gulppi, F.; Gonzalez-Hormazabal, P.; Fernandez-Ramires, R.; Bravo, T.; Reyes, J.M.; Gomez, F.; Waugh, E.; Jara, L. Association of single nucleotide polymorphisms in pre-miR-27a, pre-miR-196a2, pre-miR-423, miR-608 and pre-miR-618 with breast cancer susceptibility in a South American population. BMC Genet. 2016, 17, 109. [CrossRef] [PubMed]

37. Wang, P.Y.; Gao, Z.H.; Jiang, Z.H.; Li, X.X.; Jiang, B.F.; Xie, S.Y. The associations of single nucleotide polymorphisms in miR-146a, miR-196a and miR-499 with breast cancer susceptibility. PLoS ONE 2013, 8, e70656. [CrossRef] [PubMed]

38. Li, W.; Duan, R.; Kooy, F.; Sherman, S.L.; Zhou, W.; Jin, P. Germline mutation of microRNA-125a is associated with breast cancer. J. Med. Genet. 2009, 46, 358-360. [CrossRef] [PubMed]

39. Peterlongo, P.; Caleca, L.; Cattaneo, E.; Ravagnani, F.; Bianchi, T.; Galastri, L.; Bernard, L.; Ficarazzi, F.; Dall'olio, V.; Marme, F.; et al. The rs12975333 variant in the miR-125a and breast cancer risk in Germany, Italy, Australia and Spain. J. Med. Genet. 2011, 48, 703-704. [CrossRef] [PubMed]

40. Quann, K.; Jing, Y.; Rigoutsos, I. Post-transcriptional regulation of BRCA1 through its coding sequence by the miR-15/107 group of miRNAs. Front. Genet. 2015, 6, 242. [CrossRef] [PubMed]

41. Moskwa, P.; Buffa, F.M.; Pan, Y.; Panchakshari, R.; Gottipati, P.; Muschel, R.J.; Beech, J.; Kulshrestha, R.; Abdelmohsen, K.; Weinstock, D.M.; et al. miR-182-mediated downregulation of BRCA1 impacts DNA repair and sensitivity to PARP inhibitors. Mol. Cell 2011, 41, 210-220. [CrossRef] [PubMed]

42. Georges, S.A.; Biery, M.C.; Kim, S.Y.; Schelter, J.M.; Guo, J.; Chang, A.N.; Jackson, A.L.; Carleton, M.O.; Linsley, P.S.; Cleary, M.A.; et al. Coordinated regulation of cell cycle transcripts by p53-Inducible microRNAs, miR-192 and miR-215. Cancer Res. 2008, 68, 10105-10112. [CrossRef] [PubMed]

43. Shen, J.; Ambrosone, C.B.; DiCioccio, R.A.; Odunsi, K.; Lele, S.B.; Zhao, H. A functional polymorphism in the miR-146a gene and age of familial breast/ovarian cancer diagnosis. Carcinogenesis 2008, 29, 1963-1966. [CrossRef] [PubMed]

44. Mu, K.; Wu, Z.Z.; Yu, J.P.; Guo, W.; Wu, N.; Wei, L.J.; Zhang, H.; Zhao, J.; Liu, J.T. Meta-analysis of the association between three microRNA polymorphisms and breast cancer susceptibility. Oncotarget 2017, 8, 68809-68824. [CrossRef] [PubMed]

45. Akkiz, H.; Bayram, S.; Bekar, A.; Akgollu, E.; Uskudar, O.; Sandikci, M. No association of pre-microRNA-146a rs2910164 polymorphism and risk of hepatocellular carcinoma development in Turkish population: A case-control study. Gene 2011, 486, 104-109. [CrossRef] [PubMed]

46. Ma, X.P.; Zhang, T.; Peng, B.; Yu, L.; Jiang, D.K. Association between microRNA polymorphisms and cancer risk based on the findings of 66 case-control studies. PLoS ONE 2013, 8, e79584. [CrossRef] [PubMed]

47. Landgraf, P.; Rusu, M.; Sheridan, R.; Sewer, A.; Iovino, N.; Aravin, A.; Pfeffer, S.; Rice, A.; Kamphorst, A.O.; Landthaler, M.; et al. A mammalian microRNA expression atlas based on small RNA library sequencing. Cell 2007, 129, 1401-1414. [CrossRef] [PubMed]

48. Qi, P.; Dou, T.H.; Geng, L.; Zhou, F.G.; Gu, X.; Wang, H.; Gao, C.F. Association of a variant in MIR 196A2 with susceptibility to hepatocellular carcinoma in male Chinese patients with chronic hepatitis B virus infection. Hum. Immunol. 2010, 71, 621-626. [CrossRef] [PubMed]

49. Li, X.; Wang, J.; Jia, Z.; Cui, Q.; Zhang, C.; Wang, W.; Chen, P.; Ma, K.; Zhou, C. MiR-499 regulates cell proliferation and apoptosis during late-stage cardiac differentiation via Sox6 and cyclin D1. PLoS ONE 2013, 8, e74504. [CrossRef] [PubMed] 
50. Tian, T.; Shu, Y.; Chen, J.; Hu, Z.; Xu, L.; Jin, G.; Liang, J.; Liu, P.; Zhou, X.; Miao, R.; et al. A functional genetic variant in microRNA-196a2 is associated with increased susceptibility of lung cancer in Chinese. Cancer Epidemiol. Biomark. Prev. 2009, 18, 1183-1187. [CrossRef] [PubMed]

51. Srivastava, K.; Srivastava, A.; Mittal, B. Common genetic variants in pre-microRNAs and risk of gallbladder cancer in North Indian population. J. Hum. Genet. 2010, 55, 495-499. [CrossRef] [PubMed]

52. Liu, Z.; Li, G.; Wei, S.; Niu, J.; El-Naggar, A.K.; Sturgis, E.M.; Wei, Q. Genetic variants in selected pre-microRNA genes and the risk of squamous cell carcinoma of the head and neck. Cancer 2010, 116, 4753-4760. [CrossRef] [PubMed]

53. Zhou, J.; Lv, R.; Song, X.; Li, D.; Hu, X.; Ying, B.; Wei, Y.; Wang, L. Association between two genetic variants in miRNA and primary liver cancer risk in the Chinese population. DNA Cell Biol. 2012, 31, 524-530. [CrossRef] [PubMed]

54. Min, K.T.; Kim, J.W.; Jeon, Y.J.; Jang, M.J.; Chong, S.Y.; Oh, D.; Kim, N.K. Association of the miR-146aC>G, $149 \mathrm{C}>\mathrm{T}, 196 \mathrm{a} 2 \mathrm{C}>\mathrm{T}$, and $499 \mathrm{~A}>\mathrm{G}$ polymorphisms with colorectal cancer in the Korean population. Mol. Carcinog. 2012, 51 (Suppl. 1), E65-E73. [CrossRef] [PubMed]

55. Schulman, B.R.; Esquela-Kerscher, A.; Slack, F.J. Reciprocal expression of lin-41 and the microRNAs let-7 and mir-125 during mouse embryogenesis. Dev. Dyn. 2005, 234, 1046-1054. [CrossRef] [PubMed]

56. Wu, L.; Belasco, J.G. Micro-RNA regulation of the mammalian lin-28 gene during neuronal differentiation of embryonal carcinoma cells. Mol. Cell. Biol. 2005, 25, 9198-9208. [CrossRef] [PubMed]

57. Scott, G.K.; Goga, A.; Bhaumik, D.; Berger, C.E.; Sullivan, C.S.; Benz, C.C. Coordinate suppression of ERBB2 and ERBB3 by enforced expression of micro-RNA miR-125a or miR-125b. J. Biol. Chem. 2007, 282, 1479-1486. [CrossRef] [PubMed]

58. Iorio, M.V.; Ferracin, M.; Liu, C.G.; Veronese, A.; Spizzo, R.; Sabbioni, S.; Magri, E.; Pedriali, M.; Fabbri, M.; Campiglio, M.; et al. microRNA gene expression deregulation in human breast cancer. Cancer Res. 2005, 65, 7065-7070. [CrossRef] [PubMed]

59. Duan, R.; Pak, C.; Jin, P. Single nucleotide polymorphism associated with mature miR-125a alters the processing of pri-miRNA. Hum. Mol. Genet. 2007, 16, 1124-1131. [CrossRef] [PubMed]

60. Hu, Y.; Yu, C.Y.; Wang, J.L.; Guan, J.; Chen, H.Y.; Fang, J.Y. microRNA sequence polymorphisms and the risk of different types of cancer. Sci. Rep. 2014, 4, 3648. [CrossRef] [PubMed]

61. Gonzalez-Hormazabal, P.; Gutierrez-Enriquez, S.; Gaete, D.; Reyes, J.M.; Peralta, O.; Waugh, E.; Gomez, F.; Margarit, S.; Bravo, T.; Blanco, R.; et al. Spectrum of $B R C A 1 / 2$ point mutations and genomic rearrangements in high-risk breast/ovarian cancer Chilean families. Breast Cancer Res. Treat. 2011, 126, 705-716. [CrossRef] [PubMed]

62. Chomczynski, P.; Sacchi, N. The single-step method of RNA isolation by acid guanidinium thiocyanate-phenol-chloroform extraction: Twenty-something years on. Nat. Protoc. 2006, 1, 581-585. [CrossRef] [PubMed]

63. Untergasser, A.; Cutcutache, I.; Koressaar, T.; Ye, J.; Faircloth, B.C.; Remm, M.; Rozen, S.G. Primer3-New capabilities and interfaces. Nucleic Acids Res. 2012, 40, e115. [CrossRef] [PubMed]

64. Moazzeni, H.; Najafi, A.; Khani, M. Identification of direct target genes of miR-7, miR-9, miR-96, and miR-182 in the human breast cancer cell lines MCF-7 and MDA-MB-231. Mol. Cell. Probes 2017, 34, 45-52. [CrossRef] [PubMed]

65. Ruan, K.; Fang, X.; Ouyang, G. MicroRNAs: Novel regulators in the hallmarks of human cancer. Cancer Lett. 2009, 285, 116-126. [CrossRef] [PubMed]

66. Ryan, B.M.; Robles, A.I.; Harris, C.C. Genetic variation in microRNA networks: The implications for cancer research. Nat. Rev. Cancer 2010, 10, 389-402. [CrossRef] [PubMed]

67. Afsharzadeh, S.M.; Mohaddes Ardebili, S.M.; Seyedi, S.M.; Karimian Fathi, N.; Mojarrad, M. Association between rs11614913, rs3746444, rs2910164 and occurrence of breast cancer in Iranian population. Meta Gene 2017, 11, 20-25. [CrossRef]

68. Bansal, C.; Sharma, K.L.; Misra, S.; Srivastava, A.N.; Mittal, B.; Singh, U.S. Common genetic variants in pre-microRNAs and risk of breast cancer in the North Indian population. Ecancermedicalscience 2014, 8, 473. [PubMed]

69. He, B.; Pan, Y.; Xu, Y.; Deng, Q.; Sun, H.; Gao, T.; Wang, S. Associations of polymorphisms in microRNAs with female breast cancer risk in Chinese population. Tumour Biol. 2015, 36, 4575-4582. [CrossRef] [PubMed] 
70. Srivastava, K.; Srivastava, A. Comprehensive review of genetic association studies and meta-analyses on miRNA polymorphisms and cancer risk. PLoS ONE 2012, 7, e50966. [CrossRef] [PubMed]

71. Gao, L.B.; Bai, P.; Pan, X.M.; Jia, J.; Li, L.J.; Liang, W.B.; Tang, M.; Zhang, L.S.; Wei, Y.G.; Zhang, L. The association between two polymorphisms in pre-miRNAs and breast cancer risk: A meta-analysis. Breast Cancer Res. Treat. 2011, 125, 571-574. [CrossRef] [PubMed]

72. Zhang, H.; Zhang, Y.; Yan, W.; Wang, W.; Zhao, X.; Ma, X.; Gao, X.; Zhang, S. Association between three functional microRNA polymorphisms (miR-499 rs3746444, miR-196a rs11614913 and miR-146a rs2910164) and breast cancer risk: A meta-analysis. Oncotarget 2017, 8, 393-407. [CrossRef] [PubMed]

73. Cruz-Coke, R. Ethnic origin and evolution of the Chilean population. Rev. Med. Chile 1976, 104, $365-368$. [PubMed]

74. Valenzuela, C.Y.; Acuna, M.P.; Harb, Z. Sociogenetic gradient in the Chilean population. Rev. Med. Chile 1987, 115, 295-299. [PubMed]

75. Valenzuela, C.Y.; Harb, Z. Socioeconomic assortative mating in Santiago, Chile: A demonstration using stochastic matrices of mother-child relationships applied to ABO blood groups. Soc. Biol. 1977, 24, 225-233. [CrossRef] [PubMed]

76. Fan, C.; Chen, C.; Wu, D. The association between common genetic variant of microRNA-499 and cancer susceptibility: A meta-analysis. Mol. Biol. Rep. 2013, 40, 3389-3394. [CrossRef] [PubMed]

77. Omrani, M.; Hashemi, M.; Eskandari-Nasab, E.; Hasani, S.S.; Mashhadi, M.A.; Arbabi, F.; Taheri, M. hsa-miR-499 rs3746444 gene polymorphism is associated with susceptibility to breast cancer in an Iranian population. Biomark. Med. 2014, 8, 259-267. [CrossRef] [PubMed]

78. Dai, Z.M.; Kang, H.F.; Zhang, W.G.; Li, H.B.; Zhang, S.Q.; Ma, X.B.; Lin, S.; Wang, M.; Feng, Y.J.; Liu, K.; et al. The associations of single nucleotide polymorphisms in miR196a2, miR-499, and miR-608 with breast cancer susceptibility: A STROBE-compliant observational study. Medicine 2016, 95, e2826. [CrossRef] [PubMed]

79. Chen, P.; Zhang, J.; Zhou, F. miR-499 rs3746444 polymorphism is associated with cancer development among Asians and related to breast cancer susceptibility. Mol. Biol. Rep. 2012, 39, 10433-10438. [CrossRef] [PubMed]

80. Fuentes, M.; Pulgar, I.; Gallo, C.; Bortolini, M.C.; Canizales-Quinteros, S.; Bedoya, G.; Gonzalez-Jose, R.; Ruiz-Linares, A.; Rothhammer, F. Gene geography of Chile: Regional distribution of American, European and African genetic contributions. Rev. Med. Chile 2014, 142, 281-289. [CrossRef] [PubMed]

81. Muinos-Gimeno, M.; Montfort, M.; Bayes, M.; Estivill, X.; Espinosa-Parrilla, Y. Design and evaluation of a panel of single-nucleotide polymorphisms in microRNA genomic regions for association studies in human disease. Eur. J. Hum. Genet. 2010, 18, 218-226. [CrossRef] [PubMed]

82. Miao, L.; Wang, L.; Zhu, L.; Du, J.; Zhu, X.; Niu, Y.; Wang, R.; Hu, Z.; Chen, N.; Shen, H.; et al. Association of microRNA polymorphisms with the risk of head and neck squamous cell carcinoma in a Chinese population: A case-control study. Chin. J. Cancer 2016, 35, 77. [CrossRef] [PubMed]

83. Song, C.; Zhang, L.; Wang, J.; Huang, Z.; Li, X.; Wu, M.; Li, S.; Tang, H.; Xie, X. High expression of microRNA-183/182/96 cluster as a prognostic biomarker for breast cancer. Sci. Rep. 2016, 6, 24502. [CrossRef] [PubMed]

84. Dambal, S.; Shah, M.; Mihelich, B.; Nonn, L. The microRNA-183 cluster: The family that plays together stays together. Nucleic Acids Res. 2015, 43, 7173-7188. [CrossRef] [PubMed]

85. Li, P.; Sheng, C.; Huang, L.; Zhang, H.; Cheng, Z.; Zhu, Q. miR-183/-96/-182 cluster is up-regulated in most breast cancers and increases cell proliferation and migration. Breast Cancer Res. 2014, 16, 473. [CrossRef] [PubMed]

86. Krishnan, K.; Steptoe, A.L.; Martin, H.C.; Wani, S.; Nones, K.; Waddell, N.; Mariasegaram, M.; Simpson, P.T.; Lakhani, S.R.; Gabrielli, B.; et al. microRNA-182-5p targets a network of genes involved in DNA repair. RNA 2013, 19, 230-242. [CrossRef] [PubMed]

87. Guttilla, I.K.; White, B.A. Coordinate regulation of FOXO1 by miR-27a, miR-96, and miR-182 in breast cancer cells. J. Biol. Chem. 2009, 284, 23204-23216. [CrossRef] [PubMed]

88. Zhang, J.; Kong, X.; Li, J.; Luo, Q.; Li, X.; Shen, L.; Chen, L.; Fang, L. miR-96 promotes tumor proliferation and invasion by targeting RECK in breast cancer. Oncol. Rep. 2014, 31, 1357-1363. [CrossRef] [PubMed]

89. Yuan, S.H.; Qiu, Z.; Ghosh, A. TOX3 regulates calcium-dependent transcription in neurons. Proc. Natl. Acad. Sci. USA 2009, 106, 2909-2914. [CrossRef] [PubMed] 
90. Maia, A.T.; Spiteri, I.; Lee, A.J.; O'Reilly, M.; Jones, L.; Caldas, C.; Ponder, B.A. Extent of differential allelic expression of candidate breast cancer genes is similar in blood and breast. Breast Cancer Res. 2009, 11, R88. [CrossRef] [PubMed]

91. Seksenyan, A.; Kadavallore, A.; Walts, A.E.; de la Torre, B.; Berel, D.; Strom, S.P.; Aliahmad, P.; Funari, V.A.; Kaye, J. TOX3 is expressed in mammary $\mathrm{ER}^{+}$epithelial cells and regulates ER target genes in luminal breast cancer. BMC Cancer 2015, 15, 22. [CrossRef] [PubMed]

92. Easton, D.F.; Pooley, K.A.; Dunning, A.M.; Pharoah, P.D.; Thompson, D.; Ballinger, D.G.; Struewing, J.P.; Morrison, J.; Field, H.; Luben, R.; et al. Genome-wide association study identifies novel breast cancer susceptibility loci. Nature 2007, 447, 1087-1093. [CrossRef] [PubMed]

93. Ruiz-Narvaez, E.A.; Rosenberg, L.; Cozier, Y.C.; Cupples, L.A.; Adams-Campbell, L.L.; Palmer, J.R. Polymorphisms in the TOX3/LOC643714 locus and risk of breast cancer in African-American women. Cancer Epidemiol. Biomark. Prev. 2010, 19, 1320-1327. [CrossRef] [PubMed]

94. Slattery, M.L.; Baumgartner, K.B.; Giuliano, A.R.; Byers, T.; Herrick, J.S.; Wolff, R.K. Replication of five GWAS-identified loci and breast cancer risk among Hispanic and non-Hispanic white women living in the Southwestern United States. Breast Cancer Res. Treat. 2011, 129, 531-539. [CrossRef] [PubMed]

95. Stacey, S.N.; Manolescu, A.; Sulem, P.; Rafnar, T.; Gudmundsson, J.; Gudjonsson, S.A.; Masson, G.; Jakobsdottir, M.; Thorlacius, S.; Helgason, A.; et al. Common variants on chromosomes 2q35 and 16q12 confer susceptibility to estrogen receptor-positive breast cancer. Nat. Genet. 2007, 39, 865-869. [CrossRef] [PubMed]

96. Udler, M.S.; Ahmed, S.; Healey, C.S.; Meyer, K.; Struewing, J.; Maranian, M.; Kwon, E.M.; Zhang, J.; Tyrer, J.; Karlins, E.; et al. Fine scale mapping of the breast cancer 16q12 locus. Hum. Mol. Genet. 2010, 19, 2507-2515. [CrossRef] [PubMed]

97. Riaz, M.; Berns, E.M.; Sieuwerts, A.M.; Ruigrok-Ritstier, K.; de Weerd, V.; Groenewoud, A.; Uitterlinden, A.G.; Look, M.P.; Klijn, J.G.; Sleijfer, S.; et al. Correlation of breast cancer susceptibility loci with patient characteristics, metastasis-free survival, and mRNA expression of the nearest genes. Breast Cancer Res. Treat. 2012, 133, 843-851. [CrossRef] [PubMed] 